\title{
Phenotypic Differentiation during Migration of Dopaminergic Progenitor Cells to the Olfactory Bulb
}

\author{
Harriet Baker, Nian Liu, Hong S. Chun, Sachiko Saino, RoseAnn Berlin, Bruce Volpe, and Jin H. Son \\ Burke Medical Research Institute, Weill Medical College, Cornell University, White Plains, New York 10605
}

A possible source for transplantable neurons in Parkinson's disease are adult olfactory bulb (OB) dopamine (DA) progenitors that originate in the anterior subventricular zone and reach the $\mathrm{OB}$ through the rostral migratory stream. We used adult transgenic mice expressing a lac $Z$ reporter directed by an 8.9 $\mathrm{kb}$ tyrosine hydroxylase $(\mathrm{TH})$ promoter to investigate the course of DAergic differentiation. Parallel transgene and intrinsic $\mathrm{TH}$ mRNA expression occurred during migration of DA interneurons through the mitral and superficial granule cell layers before these cells reached their final periglomerular position. Differen- tial transgene and calcium-calmodulin-dependent protein kinase IV expression distinguished two nonoverlapping populations of interneurons. Transgenic mice carrying a TH8.9kb/lacZ construct with a mutant AP-1 site demonstrated that this element confers OB DA-specific $\mathrm{TH}$ gene regulation. These results indicate that DA phenotypic determination is specific to a subset of mobile OB progenitors.

Key words: tyrosine hydroxylase; Parkinson's disease; stem cell; migration; rostral migratory stream; subventricular zone; dopamine
Delineating the mechanisms underlying development of dopaminergic (DAergic) systems is the focus of numerous studies because of its relevance to understanding the etiology of and developing restorative therapy for Parkinson's disease. The laminar organization and primarily postnatal development of the olfactory bulb (OB) make it an ideal model system for studying DA phenotypic differentiation (Hinds, 1968a,b; McLean and Shipley, 1988; Baker and Farbman, 1993). Significantly, OB interneurons, including periglomerular DA cells, are produced even in adults (Luskin, 1993; Doetsch and Alvarez-Buylla, 1996; Lois et al., 1996; Suhonen et al., 1996; Alvarez-Buylla and Temple, 1998; Doetsch et al., 1999a) thus providing an autologous source for transplantable DA neurons.

Adult OB DA neurons derive from stem cells in the anterior subventricular zone (SVZa), a remnant of the lateral ganglionic eminence that also contributes interneurons to the cortex (Anderson et al., 1997b, 1999; Wichterle et al., 1999; Parnavelas, 2000; Parnavelas et al., 2000). Dlx1/2 homeobox gene expression with $P b x 1$ and $R U 49$ in the lateral ganglionic eminence (Redmond et al., 1996; Yang et al., 1996) defined the medial pathway that gives rise to the rostral migratory stream (RMS) and OB interneurons (Anderson et al., 1999). Dlx1/2-deficient mice had reduced numbers of granule cells in the cortex as well as the OB (Anderson et al., 1997a). SVZa-derived progenitor cells migrate through the RMS to populate granule and periglomerular layers of $\mathrm{OB}(\mathrm{Be}-$ tarbet et al., 1996). DA markers including protein and mRNA for tyrosine hydroxylase (TH), the first enzyme in DA biosynthesis, were reported previously only in the periglomerular region of the OB (Stone et al., 1991; Baker and Farbman, 1993; Betarbet et al., 1996; Suhonen et al., 1996).

\footnotetext{
Received April 6, 2001; revised July 25, 2001; accepted Aug. 27, 2001.

These studies were supported by Grants AG09686 and AG14093 from the National Institute on Aging, National Institutes of Health, and by the National Parkinson's Foundation.

Correspondence should be addressed to Dr. Harriet Baker, Burke Medical Research Institute, Weill Medical College, Cornell University, 785 Mamaroneck Avenue, White Plains, NY 10605. E-mail: habaker@med.cornell.edu.

Copyright (ㄷ) 2001 Society for Neuroscience $0270-6474 / 01 / 218505-09 \$ 15.00 / 0$
}

The molecular cascades underlying differentiation of DA neurons during embryogenesis and in adults may differ in the substantia nigra (SN) and OB based on expression of key molecules and knock-out mouse experiments (Law et al., 1992; Stone et al., 1996; Zetterstrom et al., 1996, 1997; Saucedo-Cardenas et al., 1998; Ye et al., 1998; Liu and Baker, 1999; Smidt et al., 2000). Development of OB DA phenotypic expression specifically required patterned activity from olfactory receptor cells (Gesteland et al., 1982; Baker and Farbman, 1993; Puche and Shipley, 1999). In adults, TH expression was rapidly downregulated after perturbations that reduced receptor cell afferent stimulation of the $\mathrm{OB}$, including deafferentation (Nadi et al., 1981; Baker et al., 1983, 1984), odor deprivation (Brunjes et al., 1985; Baker, 1990; Stone et al., 1991; Baker et al., 1993; Cho et al., 1996), or targeted deletion of the olfactory nucleotide-gated channel subunit 1 (Baker et al., 1999). Transcription factor expression (Guthrie and Gall, 1995b; Jin et al., 1996) and gel shift analysis of nuclear protein binding activity (Liu et al., 1999) suggested a role for the AP-1 site in activity-dependent $\mathrm{TH}$ gene regulation in OB DA neurons.

None of the above studies addressed the issue of when and where $\mathrm{OB}$ progenitor cells attain the capacity to differentiate into DA neurons. This question was examined in transgenic mice produced in our laboratory that exhibit high-level tissue-specific expression of a construct with $8.9 \mathrm{~kb}$ of $\mathrm{TH}$ promoter driving a lacZ reporter gene (Min et al., 1994). The findings suggested the existence of two populations of granule cells, only one of which is capable of differentiating into DA neurons.

\section{MATERIALS AND METHODS}

Animals and surgery. All procedures were performed under protocols approved by the Institutional Animal Care and Use Committee of Cornell University and conformed to National Institutes of Health Guidelines. Adult transgenic TH8.9kb/lac Z mice were produced in our laboratory as described previously (Min et al., 1994). These mice were one of the six lines derived that exhibited high-level lac $Z$ expression that is specific to catecholamine-expressing neurons (Min et al., 1994). The production of the mice with the mutant AP-1 site is described below. Naris closure was performed as described previously under pentobarbital 
A

Figure 1. TH protein and mRNA in a mouse OB. $A$, Immunoreactivity for TH protein is restricted to periglomerular cells of the glomerular $(g l)$ layer and a few cells in the mitral $(\mathrm{m})$ cell layer (arrows, $B$ ) and in the accessory olfactory bulb (arrowheads, $A$ ). The inset in $B$ shows periglomerular cells at higher magnification; filled arrowheads show a cell and its dendrite ramifying in a glomerulus; the open arrowhead indicates an interglomerular process, presumably an axon. The boxed area delineates the region shown in the inset. $C, D$, TH mRNA is found in the glomerular, mitral, and superficial granule ( $g r$ ) cell layers. The RMS does not display either $\mathrm{TH}$ protein or mRNA. CTX, Cortex; $g$, glomerulus. Scale bars: $A, C, 650 \mu \mathrm{m} ; B, D, 100 \mu \mathrm{m}$; inset, $35 \mu \mathrm{m}$.
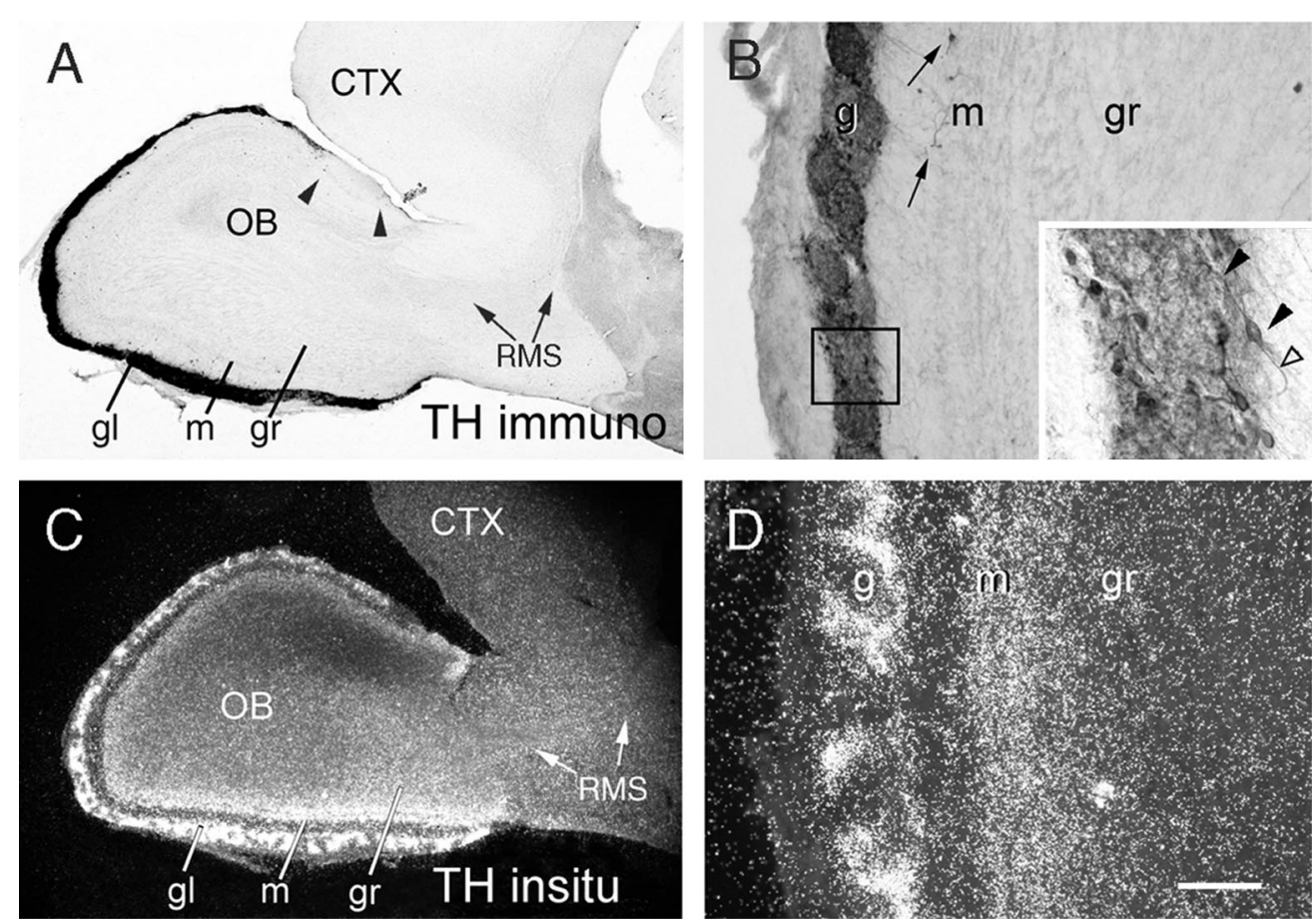

anesthesia (30 mg/kg) using a bipolar coagulator (Liu et al., 1999). Mice were killed at least 2 months after closure. All animals were housed under a $12 \mathrm{hr}$ light/dark cycle with food and water ad libitum.

For immunohistochemical, histochemical, and in situ hybridization procedures, mice were anesthetized with an overdose of pentobarbital $(90 \mathrm{mg} / \mathrm{kg})$. They were then perfused transcardially with saline containing $0.5 \%$ sodium nitrite and $10 \mathrm{U} / \mathrm{ml}$ of heparin followed by either phosphate-buffered [0.1 M phosphate buffer (PB), $\mathrm{pH} 7.2] 4 \%$ formaldehyde (for immunocytochemistry and in situ hybridization) or $2.5 \%$ glutaraldehyde and $0.5 \%$ formaldehyde [for 5-bromo-4-chloro-3-indolyl- $\beta$ D-galactopyranoside (X-Gal) histochemistry]. Brains were removed, post-fixed, rinsed in buffer, and cryoprotected in sucrose before sections $(40 \mu \mathrm{m})$ were prepared on a sliding microtome.

Construction of TH8.9kb AP-1 mutant/lacZ fusion DNA. The original TH8.9kb/lacZ DNA construct (Min et al., 1994) was used to generate a TH8.9kb AP-1 mutant/lac $Z$ fusion DNA construct by replacing the 0.2 kb $X b a \mathrm{I}-B g l \mathrm{II}$ DNA fragment containing the TH AP-1 site (5'TGATTCA-3') located at -200 bp upstream of the start codon with an $0.2 \mathrm{~kb} X b a \mathrm{I}-B g l \mathrm{II}$ fragment with two mutated nucleotides (underlined) $\left(5^{\prime}\right.$-TGTTTAA- $\left.3^{\prime}\right)$. To generate the AP-1 double mutation, site-directed mutagenesis was performed using double-stranded plasmid as the template based on published procedures (Inouye and Inouye, 1987) as described previously (Tinti et al., 1997). DNA sequencing analysis confirmed the AP-1 double mutation. Of the four transgenic lines generated, reporter gene expression was similar in three lines (lines 7, 19, and 20), as described previously. The fourth exhibited ectopic glial staining and was not analyzed further. Transfectional studies in SK-N-BE(2)C cells demonstrated the specificity and effectiveness of these mutations in the AP-1 site in the context of a $5.6 \mathrm{~kb}$ TH-chloramphenicol acetyltransferase construct. Basal and 12-O-tetradecanoylphorbol-13-acetateinducible TH promoter activity were reduced in SK-N-BE(2) cells transfected with the mutated construct. Electromobility shift analysis demonstrated loss of nuclear protein binding activity to the mutant AP-1 site (Liu et al., 1998).

Immunocytochemical procedures. For localization of a single antigen, free-floating sections were processed as described previously (Cho et al., 1996). Briefly, tissue was blocked with $1 \%$ bovine serum albumin and $0.2 \%$ Triton X-100 in PBS and incubated overnight with primary antisera. The TH rabbit antibody (1:25,000 final concentration) was raised in our laboratory. Rabbit antibacterial $\beta$-galactosidase ( $\beta$-gal) (1:5000) was obtained from ICN Pharmaceuticals (Aurora, $\mathrm{OH}$ ), monoclonal $\mathrm{CaM}$ kinase II (CaMKII) $(0.2 \mu \mathrm{g} / \mathrm{ml})$ was purchased from Boehringer Mannheim (Indianapolis, IN), and CaM kinase IV (CaMKIV) (1:2000) was obtained from Santa Cruz Biotechnology (Santa Cruz, CA). Antigens were visualized by incubation with appropriate biotinylated secondary antisera and the Vector Elite kit (Vector Laboratories, Burlingame, CA) and $3,3^{\prime}$-diaminobenzidine $(0.05 \%)$ and hydrogen peroxide $(0.003 \%)$ as chromogen. Sections were mounted on slides, dehydrated through graded alcohols, and coverslipped.

For double-label immunocytochemistry, sections were incubated with primary antibodies and then with appropriate secondary antibodies conjugated to either fluorescein or rhodamine (Jackson ImmunoResearch, West Grove, PA). A monoclonal TH antibody, used at a dilution of 1:5000, was purchased from Boehringer Mannheim. CaMKIV and $\beta$-gal antibodies were used at dilutions of 1:200 and 1:750, respectively, and viewed on a Nikon confocal microscope (Nikon, Melville, NY).

In situ hybridization. Mice were perfused as described above except that all solutions used after fixation were prepared in DEPC-treated water. Sections $(40 \mu \mathrm{m})$ were collected in either $2 \times$ (for radiolabeling) or $4 \times$ (for digoxigenin-labeling) SSC in vials on ice. For radiolabeling of mRNA, sections were hybridized with a $1.6 \mathrm{~kb}$ TH probe labeled by random priming with ${ }^{35} \mathrm{~S}$-dATP $\left(10^{7} \mathrm{dpm} / \mathrm{ml}\right)$ as described previously (Cho et al., 1996). Hybridization buffer contained $2 \times$ SSC, $50 \%$ formamide, $1 \times$ Tris EDTA dextran sulfate (TED), $1.6 \mathrm{mg} / \mathrm{ml}$ salmon sperm DNA, and $4 \times$ Denhart's solution. Hybridization occurred overnight at $48^{\circ} \mathrm{C}$. Tissue was washed, mounted on slides, apposed to Kodak X-Omat film (Eastman Kodak, Rochester, NY), and then dipped in nuclear-type $\mathrm{B} 2$ emulsion for $\sim 2$ weeks at $4^{\circ} \mathrm{C}$. Slides were developed, counterstained, dehydrated, and coverslipped. For preparation of digoxigenin-labeled probes, template DNA was linearized and transcribed with T7 RNA polymerase for the antisense orientation. The hybridization buffer contained $4 \times$ SSC, $50 \%$ formamide, $0.2 \times$ TED, $0.56 \mathrm{mg} / \mathrm{ml}$ of salmon sperm DNA, $4 \times$ Denhart's solution, and $250 \mu \mathrm{g} / \mathrm{ml}$ transfer RNA. After hybridization overnight at $60^{\circ} \mathrm{C}$, sections were washed at $65^{\circ} \mathrm{C}$. Message was demonstrated by either an alkaline phosphatase- or fluorescein-labeled secondary antibody to digoxigenin (Boehringer Mannheim). The chromogen $[0.33 \mathrm{mg} / \mathrm{ml}$ nitroblue tetrazolium (NBT) and $0.16 \mathrm{mg} / \mathrm{ml}$ 5-bromo-4-chloro-3-indolyl phosphate (BCIP)] was used to detect alkaline phosphatase.

$X$-Gal staining. Tissue sections were incubated overnight with a solution containing $3.1 \mathrm{~mm}$ potassium ferricyanide, $3.1 \mathrm{~mm}$ potassium ferrocyanide, $0.15 \mathrm{M} \mathrm{NaCl}, 1 \mathrm{~mm} \mathrm{MgCl}_{2}, 0.01 \%$ sodium deoxycholate, $0.02 \%$ Nonidet P-40, and $0.2 \mathrm{mg} / \mathrm{ml} \mathrm{X-Gal} \mathrm{in} 10 \mathrm{~mm} \mathrm{~PB}, \mathrm{pH} 7.4$, as described previously (Min et al., 1996)

$\beta$-Gal assay. A $\beta$-gal assay kit (catalog no. GAL-A; Sigma, St. Louis, MO) was used according to the manufacturer's directions. OBs and SNs were obtained by regional brain dissections. The $\mathrm{SN}$ was composed of the midbrain ventral to the cerebral aqueduct. Because the rostral limit was the mammillary bodies and the posterior limit was midpons, there was a considerable dilution of the $\sim 15,000$ DA cells in the SN compared with 
$\sim 100,000$ cells in the OB. Each OB and midbrain was homogenized in either $200 \mu \mathrm{l}$ or $400 \mu \mathrm{l}$ of lysis buffer, respectively. Fifty microliters of supernatant was reacted for either $30 \mathrm{~min}(\mathrm{OB})$ or $60 \mathrm{~min}(\mathrm{SN})$. The amount of reaction product was measured on a plate reader (Molecular Devices, Sunnyvale, CA) at $420 \mathrm{~nm}$. Activity differences, expressed in milliunits per milliliter per tissue sample, were analyzed by ANOVA with post hoc Fisher's LSD tests.

Cell counts. Cells expressing $\beta$-gal were counted on a Zeiss microscope (Zeiss, Thornwood, NY) at $600 \times$ magnification using an unbiased counting method with Zeiss KS400 software. Target cells were sampled in identically defined counting frames ipsilateral and contralateral to the naris closure. The frames were either 0.125 or $0.0125 \mathrm{~mm}^{2}$ in area for the glomerular and mitral cell layers, respectively. Cell counts represent the mean of six to eight sections per animal $(n=3)$ spanning the dorsal to ventral aspects of the OB. Data are expressed as either the number of cells per square millimeter or the total number of cells corrected for the change in OB area. The latter was determined with the KS400 software, using a cursor to outline each of the sections on which cell counts were obtained. The area correction compensated for the previously reported OB shrinkage (Baker et al., 1993). Data were analyzed by paired Student's $t$ tests.

Illustrations. All illustrations were composited in Adobe PhotoShop (Adobe Systems, San Jose, CA).

\section{RESULTS}

\section{Distribution of TH protein and mRNA in adult mouse olfactory system}

In agreement with previous findings (Baker et al., 1983; Baker and Farbman, 1993), TH protein, as demonstrated by immunostaining, occurred primarily in periglomerular and tufted cells distributed around the glomeruli of the main olfactory bulb (Fig. $1 A$ ). The intraglomerular processes of these cells also displayed high levels of TH immunoreactivity (Fig. $1 B$, inset). Infrequently, immunostained cells were found in the external plexiform and mitral cell layers. The glomerular region of the accessory olfactory bulb (AOB) also contained a few TH-immunoreactive cells. TH protein could not be demonstrated within either the RMS (Fig. $1 A$ ) or the SVZa. TH mRNA, assessed by in situ hybridization using ${ }^{35} \mathrm{~S}$-radiolabeled TH probe (Fig. 1C) or digoxigeninlabeled TH probe (Fig. 2), exhibited high levels of expression associated with the periglomerular region surrounding the glomeruli of the main OB. Less dense accumulations of either silver grains or reaction product, indicative of low TH mRNA levels, were found in the mitral and superficial granule cell layers (Figs. $1 D, 2 B$, arrows). The external plexiform layer contained a few cells with TH mRNA (Fig. $2 B$, arrowhead). TH mRNA was also detected in the AOB (Fig. 2A, arrowhead).

\section{lacZ expression in transgenic mice}

The pattern of expression of the $8.9 \mathrm{~kb} \mathrm{TH} / \mathrm{lac} Z$ construct in the transgenic mice was the same when demonstrated by either X-Gal histochemistry or $\beta$-gal immunocytochemistry (Fig. $3 A, C$ ). The distribution of stained periglomerular cells and their intraglomerular processes were similar to those observed with $\mathrm{TH}$ antibodies. In the mitral cell layer, numerous small, granule-like cells could be demonstrated with both reporter gene detection procedures (Fig. 3B,D). The leading processes of the cells traversed the external plexiform layer to terminate either at or near the glomeruli, giving the impression that the cells were migrating toward the glomerular layer (Fig. 3D, inset). Definitive determination of intraglomerular terminations was difficult because of the presence of the heavily stained periglomerular cell processes. Superficially located granule cells also were labeled with $\beta$-gal and X-Gal (Fig. $3 B, D)$. These cells often showed leading processes directed toward the external plexiform layer, again suggesting that they were presumptive dopaminergic neurons migrating toward the glomer-
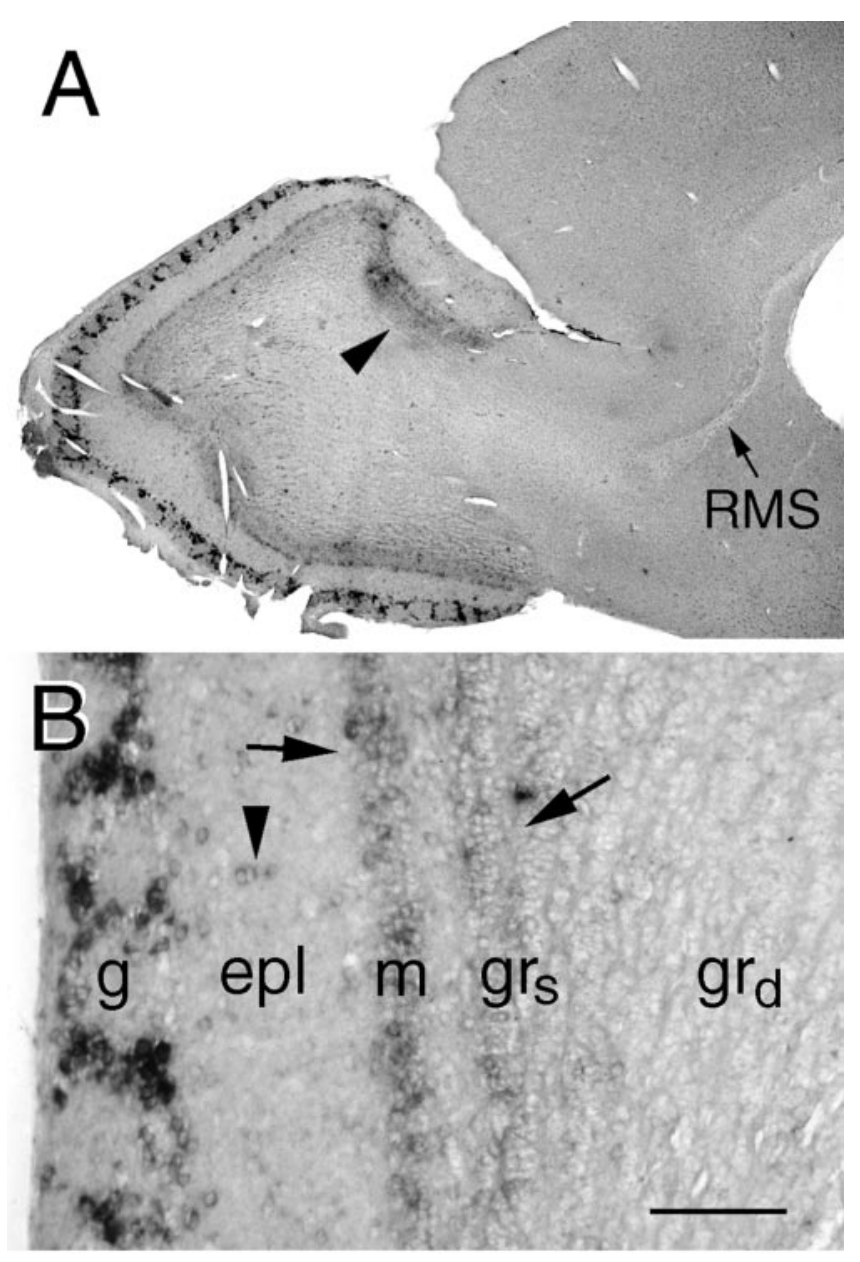

Figure 2. Tyrosine hydroxylase mRNA demonstrated by nonradioactive in situ hybridization using a digoxigenin-labeled probe and an alkaline phosphatase-conjugated antibody with NBT-BCIP as the chromogen. The low-magnification micrograph $(A)$ shows that label is found only in the olfactory bulb and not in the RMS. The arrowhead indicates the accessory olfactory bulb. $B$, The higher-magnification micrograph demonstrates that label is heavy in periglomerular cells but lighter in granule cells in the mitral $(\mathrm{m})$ and superficial granule cell $(\mathrm{gr} s)$ layers (arrows) and absent in the deep granule cell layer $\left(g r_{d}\right)$. A few presumably migrating cells (arrowhead) exhibiting light label are found in the external plexiform layer (epl). g, Glomerulus. Scale bars: $A, 700 \mu \mathrm{m} ; B, 100 \mu \mathrm{m}$.

ular layer (Figs. 3B,D, $4 B$ ). The small but consistent number of transgene-expressing cells observed in the external plexiform layer suggested rapid migration through this layer. TH mRNA (Figs. $1 C, 2 A$ ) and transgene (Fig. $3 C$ ) showed parallel distributions in the periglomerular and mitral cell layers. In the AOB, $\beta$-gal- and X-Gal-labeled cells were numerous in the granule and mitral cell layers, infrequent in the glomerular layer (Fig. $3 A, C$ ), and never associated with cellular TH immunostaining.

\section{Characterization of the $\beta$-gal cells in the mitral cell layer}

To determine whether the $\beta$-gal-immunolabeled cells in the mitral cell layer were granule or mitral cells, sections were stained with a calcium-calmodulin-dependent protein kinase II (CaMKII) antiserum (Fig. 4). Mitral cells, containing heavy cytoplasmic CaMKII staining, were clearly larger $(\sim 30-40 \mu \mathrm{m}$ in diameter) than the $\beta$-gal-labeled cells $(\sim 10 \mu \mathrm{m})$. Granule cells, which were also immunolabeled with CaMKII, displayed only a thin rim of cytoplasmic staining. 
Figure 3. Histochemical (X-Gal) and immunocytochemical ( $\beta$-gal) demonstration of transgene expression in $\mathrm{TH} 8.9 \mathrm{~kb} / \mathrm{lacZ}$-expressing mice. Both $\mathrm{X}$-Gal $(A)$ and $\beta$-gal $(C)$ label cells in the glomerular $(g l)$, mitral $(m)$, and superficial granule $(g r)$ cell layers but not in the RMS or the cortex $(C T X)$. The granule and mitral cell layers of the accessory olfactory bulb (arrowheads in $A$ and $C$ ) also exhibit transgene expression. Higher-magnification micrographs $(B, D)$ show that the leading processes of labeled cells in the mitral cell layer span the external plexiform layer (epl) and terminate near or within the glomeruli (see also Fig. 4). The highmagnification inset in $D$ (defined by the white box) shows a labeled cell in the epl (arrowhead) and leading processes (arrow). Scale bars: $A, C, 600 \mu \mathrm{m} ; B, D, 125$ $\mu \mathrm{m}$; inset, $65 \mu \mathrm{m}$.
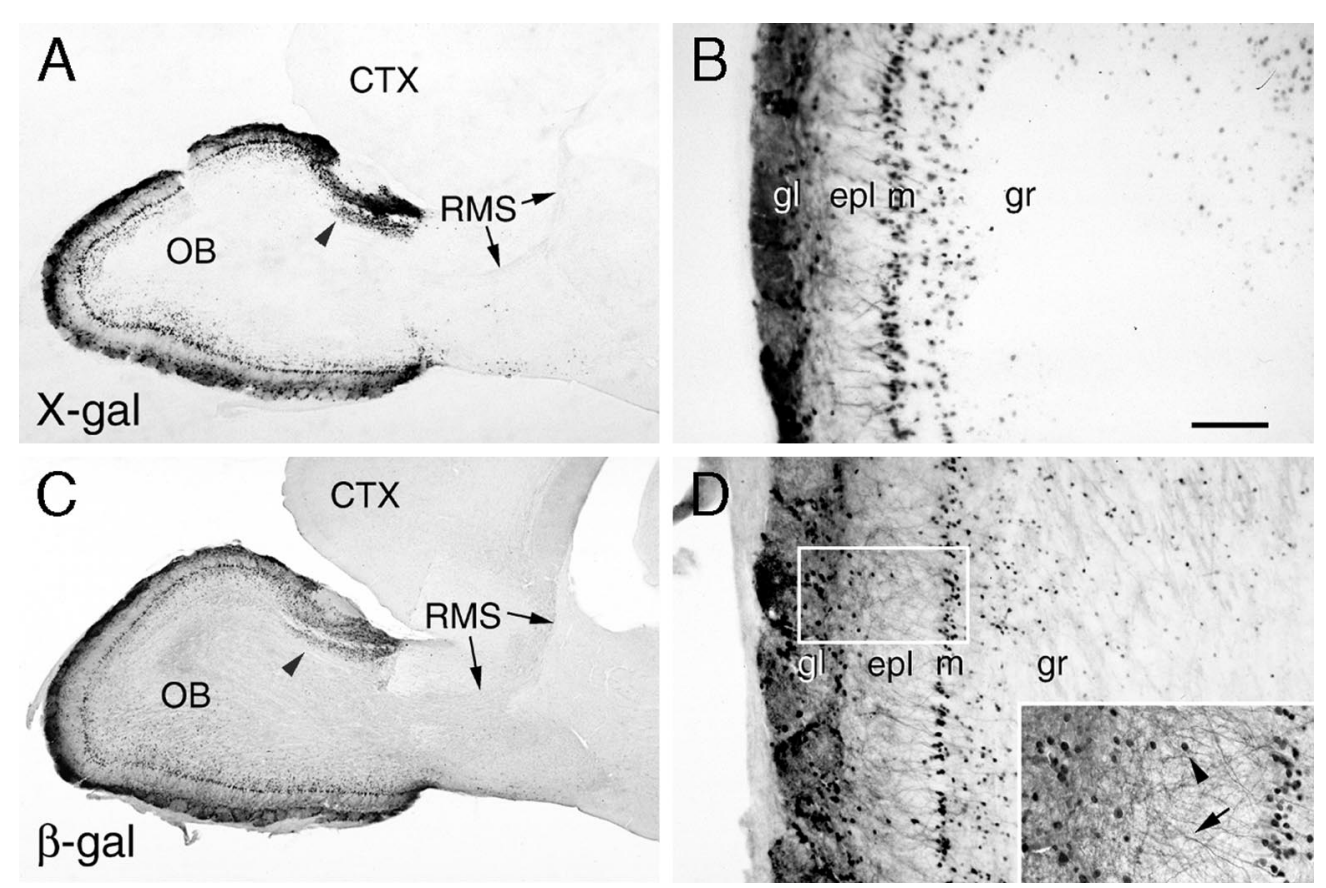

Previous studies established that DA cells in the OB (Liu, 2000) and SN (our unpublished observation) did not contain CaMKIV immunoreactivity. The current study found that other $\beta$-gal-containing regions of the $\mathrm{OB}$, the mitral and superficial granule cell layers, also were distinguished by their lack of labeling with antiserum to CaMKIV (Fig. 5A). Double-labeling studies confirmed that $\beta$-gal and CaMKIV were expressed by different granule cell populations (Fig. $5 B, C$ ), suggesting that the dopaminergic phenotype may be determined before cells reach the periglomerular region. CaMKIV staining was limited to a small population of cells in the RMS (data not shown).

\section{Colocalization of $\beta$-gal, TH immunoreactivity, and TH mRNA}

Two populations of periglomerular cells could be distinguished using rhodamine immunofluorescence for $\beta$-gal and fluorescein immunofluorescence for TH observed by confocal microscopy (Fig. 5D,E). As expected, most cells appeared yellow when images were merged, demonstrating that they contained both $\beta$-gal and TH (Fig. $5 F$ ). A few periglomerular cells contained only $\beta$-gal immunoreactivity (Fig. $5 D-G$ ). These cells were more numerous in the periglomerular region either adjacent to or within the external plexiform layer. All $\beta$-gal-immunopositive cells in the mitral and granule cell layers exhibited only red (rhodamine immunofluorescence) because they did not contain TH protein (Fig. 5G).

Double-label studies localized TH mRNA with a probe prepared with fluorescein-labeled anti-digoxigenin and $\beta$-gal protein with rhodamine-labeled secondary antibodies; these studies showed that the $\beta$-gal-containing cells in the mitral cell layer expressed low but significant levels of TH mRNA (Fig. 5H-J, $H^{\prime}-$ $\left.J^{\prime}\right)$. $\beta$-Gal immunoreactivity was somewhat reduced by the high temperature required for the in situ hybridization procedure. In contrast, TH immunoreactivity was restricted to periglomerular cells and their processes within glomeruli. TH mRNA was not observed in either the SVZa or the RMS with the fluorescent technique (data not shown).

\section{TH and $\boldsymbol{\beta}$-gal expression after olfactory deprivation}

As published previously (Min et al., 1994), $\beta$-gal expression, especially in the intraglomerular processes of the periglomerular cells, declined in parallel with $\mathrm{TH}$ immunoreactivity (data not shown) in the periglomerular region of the OB ipsilateral to unilateral naris closure (Fig. 6A,B). However, the number of $\beta$-gal-immunoreactive cells expressed per area in the medial periglomerular region was higher in the OB ipsilateral compared with contralateral to naris closure (mean number of cells per $\mathrm{mm}^{2} \pm \mathrm{SE}$ was $1372 \pm 58.7$ versus $923.2 \pm 16.0 ; p<0.002$ respectively). Naris closure produced a significant decline in the area of the $\mathrm{OB}$ [mean area in $\mathrm{mm}^{2} \pm \mathrm{SE}$ was $2.43 \pm 0.03$ (ipsilateral) versus $3.27 \pm 0.11$ (contralateral); $p<0.001]$. Thus, there was no difference in the number of periglomerular cells when adjusted for the change in $\mathrm{OB}$ area [total mean number of cells \pm SE was $3381 \pm 141$ (ipsilateral) versus $3022 \pm 95$ (contralateral); $p>0.05]$. The opposite pattern was observed in the mitral and granule cell layers, where $\beta$-gal immunoreactivity did not appear to be altered by naris closure. Expressed per unit area, the number of $\beta$-gal-immunoreactive cells in the mitral cell layer was similar [mean number of cells per $\mathrm{mm}^{2} \pm \mathrm{SE}$ was $6134 \pm$ 1000 (ipsilateral) versus $6840.2 \pm 864$ (contralateral); $p>0.05]$. When corrected for OB shrinkage, the number of granule cells in the mitral cell layer was reduced by $\sim 30 \%$ ipsilateral to closure [total mean number of cells was 14,905 \pm 2741 (ipsilateral) versus $22,366 \pm 2048$ (contralateral); $p<0.01]$.

\section{$\beta$-Gal expression in transgenic mice with a mutated AP-1 site}

Three lines of transgenic mice were derived that expressed a transgene in which two bases were mutated in the context of the $8.9 \mathrm{~kb} \mathrm{TH}$ promoter. In the $\mathrm{OB}$, transgene expression in mice expressing the mutant AP-1 construct was absent in the mitral cell layer and significantly reduced in the periglomerular region (Fig. $7 A-D$ ). In agreement with observations in transgenic mice expressing the normal $\mathrm{TH}$ promoter construct, no staining was observed in either the SVZa or RMS (data not shown). $\beta$-Gal 

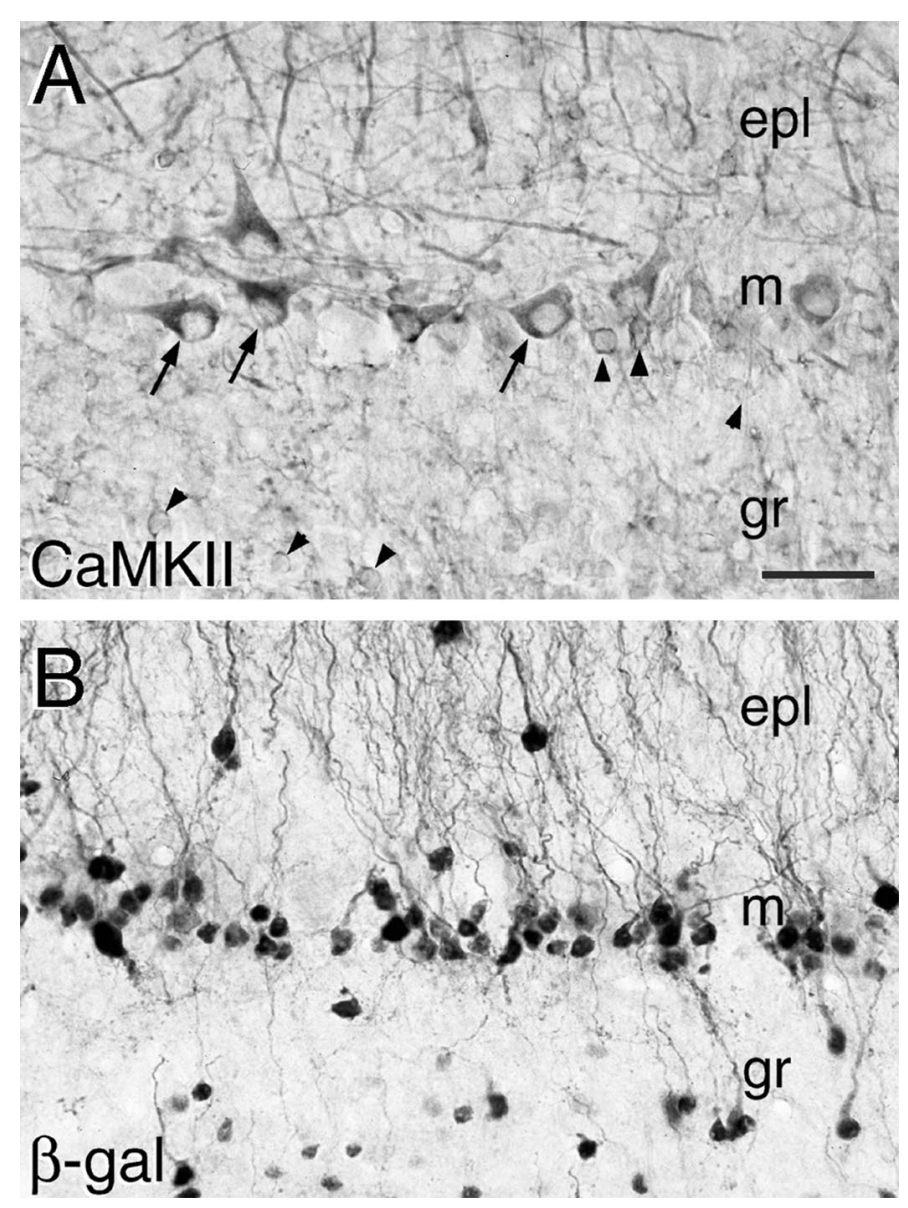

Figure 4. Comparison of CaMKII and $\beta$-gal immunostaining in the olfactory bulb of TH8.9kb/lacZ-expressing mice. CaMKII staining $(A)$ distinguishes the large mitral cells (arrows) with strong cytoplasmic label and the smaller granule cells (arrowheads) that display only a thin rim of cytoplasmic immunoreactivity. In contrast, $\beta$-gal immunostaining $(B)$ is limited to the granule cells of the mitral $(m)$ and granule $(g r)$ cell layers. The processes of these granule cells traverse the external plexiform layer (epl). Scale bars: $A, B, 50 \mu \mathrm{m}$.

activity, measured in OB homogenates, was 4- to 15-fold lower in the mutant mice compared with the mice expressing the normal promoter construct (Fig. $7 E$ ). $\beta$-Gal immunoreactivity in the SN and locus ceruleus was similar in the control and mutant transgenic mice (data not shown). Assessment of $\beta$-gal levels in tissue homogenates of the SN (Fig. $7 F$ ) showed that transgene expression was not significantly different between the control strain and two of the strains with the mutant construct (AP-1m\#19 and AP-1m\#7) but that this expression was threefold higher in the third mutant strain (AP-1m\#20). Because this latter strain displayed the lowest $\beta$-gal activity in the $\mathrm{OB}$, the results strongly support the concept that $\mathrm{TH}$ regulation through the AP-1 site shows brain region-specific regulation.

\section{DISCUSSION}

Evidence is presented to support the hypothesis that DA phenotypic expression, previously recognized only in the glomerular layer of the OB (McLean and Shipley, 1988; Baker and Farbman, 1993), can be demonstrated in the migratory pathway before the interneurons attain their final periglomerular position. Adult transgenic mice that express an $8.9 \mathrm{~kb}$ TH promoter-lac $Z$ reporter construct displayed staining for $\beta$-gal, the lac $Z$ gene product, in cells of the mitral and superficial granule cell layers using both $\mathrm{X}$-Gal histochemical and $\beta$-gal immunohistochemical techniques. CaMKII immunostaining demonstrated that the $\beta$-gal-labeled cells in the mitral cell layer were granule cells. $\beta$-Gal-stained cells were not found in either the SVZa or the RMS. The paucity of $\beta$-gal labeling in the external plexiform layer, despite the fact that neurons clearly must traverse this layer, suggested that migrating cells move rapidly from the mitral cell to the glomerular layer. Although previous studies suggested that TH mRNA and protein occurred only in the periglomerular layer in association with odor-induced activity, the presence of mRNA in the mitral cell layer could be discerned, in fact, by closer inspection of published micrographs (Stone et al., 1991; Min et al., 1996). The long half-life of the bacterial gene product $\beta$-gal in the mammalian cells may contribute to the greater number of $\beta$-gal-containing cells than both TH mRNA- and protein-containing cells.

Double-labeling studies demonstrated that almost all periglomerular cells that expressed TH protein also had $\beta$-gal immunoreactivity. Some cells, primarily adjacent to the external plexiform layer, contained only $\beta$-gal immunoreactivity. The lack of $\mathrm{TH}$ protein may reflect either newly migrating cells not yet receiving innervation or cells that have been deafferented as a consequence of normal receptor cell turnover (Graziadei and Monti Graziadei, 1980). TH mRNA but not TH protein could be demonstrated in the $\beta$-gal-immunoreactive cells in the mitral cell layer, confirming the occurrence of $\mathrm{TH}$ transcription but not translation. A recent study used an antigen retrieval system to suggest that low levels of TH protein may be found in the mitral cell layer in association with a TH-reporter gene construct (Schimmel et al., 1999). Perikaryal labeling is difficult to discern in the low magnification micrographs and could represent either fiber terminations from centrifugal noradrenergic innervation (McLean and Shipley, 1991) or the unmasking of an antigen other than TH. TH-immunostained cells could be demonstrated in the mitral cell layer of neonates (Baker and Farbman, 1993) but not in the mitral cell layer of adults (Baker et al., 1983, 1993; McLean and Shipley, 1988; Baker, 1990; Stone et al., 1990, 1991). Even assuming that low-level, leaky TH protein expression does occur, the data show that DA phenotypic differentiation is incomplete during migration.

The mechanisms that produce the dissociation between $\mathrm{TH}$ mRNA and protein expression are as yet unknown. Previous studies have clearly established that receptor afferent stimulation is necessary for full phenotypic expression of the DA phenotype. The current data suggest that a very low level of stimulation is sufficient to induce transcription, but not translation of $\mathrm{TH}$ (see below). Evidence also exists for regulation of TH mRNA levels by factors binding to the $3^{\prime}$ untranslated region, supporting the notion that altered mRNA stability may contribute to these findings, especially in view of the low mRNA levels observed in superficial granule cells (Kroll et al., 1999; Makeyev et al., 1999).

The finding that at least partial DA differentiation occurred before interneurons reached the glomerular layer raised the issue of where periglomerular and granule cells initially attain their separate phenotypes, because all interneurons migrate in the RMS. Staining for CaMKIV, shown previously to phosphorylate the transcription factor cAMP response element-binding protein that binds to the cAMP response element sites in the promoters of many genes, including $\mathrm{TH}$, was used to begin to address this issue (Enslen et al., 1994; Matthews et al., 1994). CaMKIV immunostaining revealed two distinct populations of interneurons during their migration through the $\mathrm{OB}$, a population with 

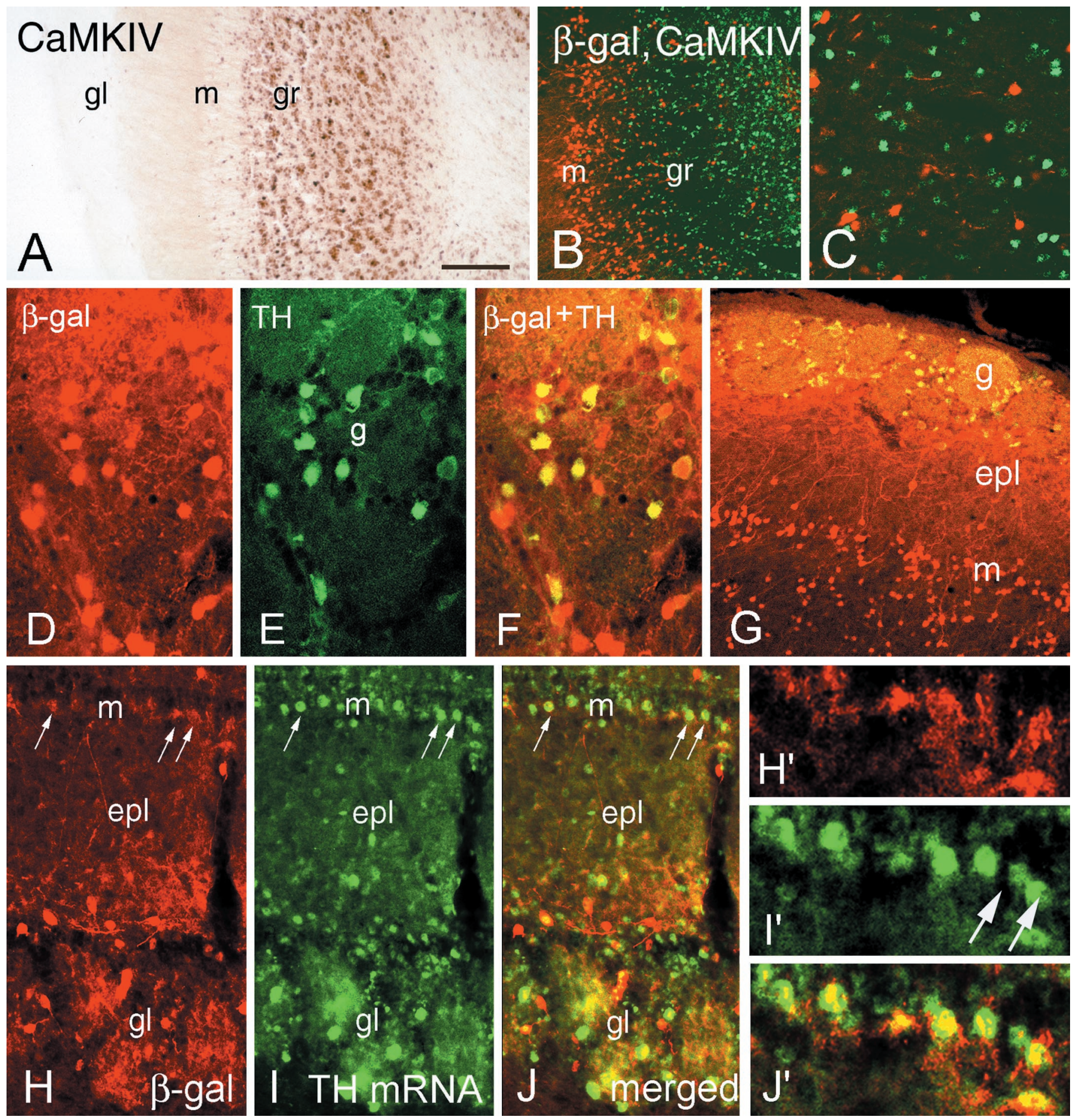

Figure 5. CaMKIV, $\beta$-gal, and TH protein and mRNA expression in the olfactory bulb. $A$, CaMKIV immunostaining is restricted to deep granule ( $g r$ ) cells. Low- $(B)$ and high- $(C)$ magnification confocal images of sections double-labeled for $\beta$-gal (red) and CaMKIV (green) illustrate the complete separation of the two antigens. Sections immunostained with $\beta$-gal $(D$, red $)$ and TH $(E$, green $)$ show the large degree of overlap between transgene and $\mathrm{TH}$ protein expression in the glomerular $(g)$ region of the olfactory bulb. In the merged image $(F)$, cells containing both antigens are yellow. $G$ shows that, in contrast to the colocalization of TH and $\beta$-gal protein in the glomerular layer, only $\beta$-gal immunostaining is observed in the mitral $(m)$ cell layer and few cells exhibit staining in the external plexiform layer (epl). The colocalization of TH mRNA and $\beta$-gal protein is shown in $H-J$. Double-labeled cells appear yellow (arrows in $H-J)$. $H^{\prime}-J^{\prime}$ are higher-magnification images of the mitral cell layer showing that TH mRNA (arrows in $\mathrm{I}^{\prime}$ ) but not TH protein is present in granule cells. Scale bars: $A, B, 130 \mu \mathrm{m} ; C, H-J, 70 \mu \mathrm{m} ; D-F, 40 \mu \mathrm{m} ; G, 90 \mu \mathrm{m} ; H^{\prime}-J^{\prime}, 20 \mu \mathrm{m}$.

$\beta$-gal immunoreactivity and another that contained only CaMKIV. Few if any CaMKIV-immunoreactive cells were observed in the RMS, suggesting that phenotypic determination may not occur until interneurons reach the granule cell layer, but before the putative DA neurons reach the periglomerular region. These findings do not rule out the possibility that differentiation may be initiated either as stem cells divide in the SVZa (Doetsch et al., 1999a,b) or at the time of terminal division during migra- 

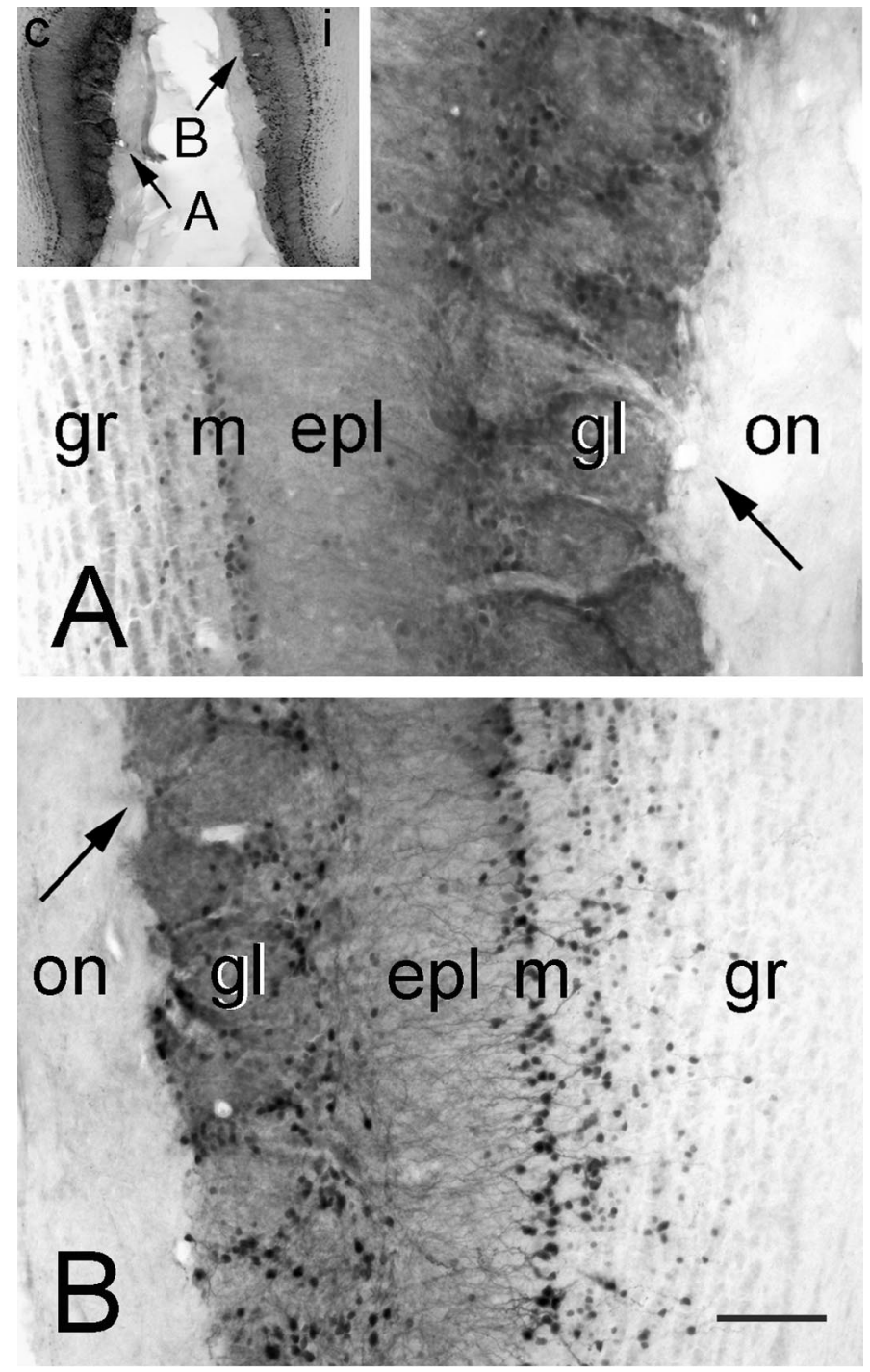

Figure 6. $\beta$-Gal immunostaining contralateral and ipsilateral to unilateral naris closure in $\mathrm{TH} 8.9 \mathrm{~kb} / \mathrm{lac} Z$-expressing mice. In the olfactory bulb contralateral $(c)$ to naris closure $(A)$, strong fiber and cellular staining are observed in the glomerular $(\mathrm{gl})$ and mitral $(m)$ cell layers. Fibers traverse the external plexiform layer $(e p l)$. Ipsilateral $(i)$ to naris closure $(B)$ cellular staining is maintained but fiber staining is dramatically reduced. The inset shows the medial aspects of the olfactory bulbs at low magnification. Letters in the inset indicate the regions illustrated at high magnification in $A$ and $B . g r$, Granule cell layer; on, olfactory nerve layer. Scale bars: $A, B, 100 \mu \mathrm{m}$; inset, $650 \mu \mathrm{m}$.

tion through the RMS (Lois and Alvarez-Buylla, 1993; Luskin, 1993; Menezes et al., 1995; Brock et al., 1998; Kirschenbaum et al., 1999).

Also addressed was whether odor deprivation, shown previously to reduce TH mRNA and protein levels (Baker, 1990; Stone et al., 1990, 1991; Baker et al., 1993; Cho et al., 1996), downregulated $\beta$-gal expression in both the glomerular and mitral cell layers. In agreement with previous findings (Baker et al., 1984, 1988; Stone et al., 1990, 1991), the number of $\beta$-gal-containing periglomerular cells in the OB ipsilateral compared with contralateral to naris closure was not altered when adjusted for the decrease in $\mathrm{OB}$ area. In contrast, a reduction was found in the number of $\beta$-gal-expressing cells in the mitral cell layer. Differential regulation in these two OB populations may occur because
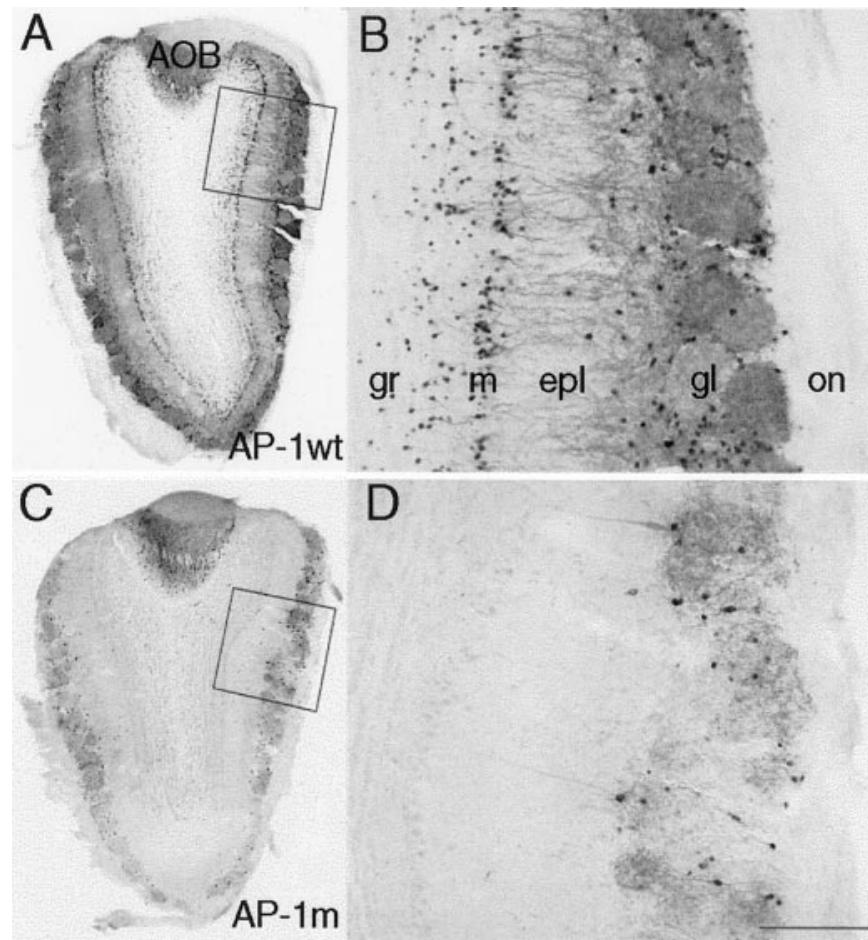

D
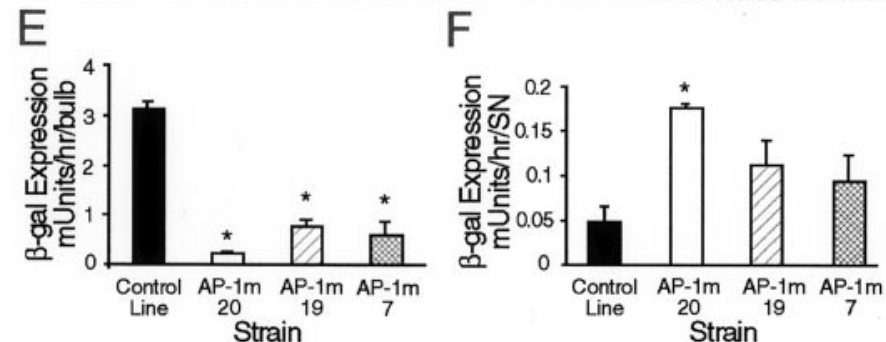

Figure 7. $\beta$-Gal immunostaining in wild-type and TH8.9kb AP-1 mu$\operatorname{tant} /$ lac $Z$ mice. Transgenic mice expressing a transgene with a normal AP-1 construct $(A, B)$ exhibit $\beta$-gal immunostaining in the granule $(g r)$, mitral $(m)$, and glomerular $(\mathrm{gl})$ layers. Mice expressing the mutant AP-1 construct show no $\beta$-gal staining in the granule and mitral cell layers and reduced staining in the glomerular layer $(C, D)$. The reduction in $\beta$-gal expression in the OBs of the TH8.9kb AP- 1 mutant/lac $Z$ mice was confirmed by assaying $\beta$-gal activity in the OB $(E)$. In the SN $(F), \beta$-gal was either the same or higher in mice expressing the mutant construct. Asterisks in $E$ and $F$ indicate significant differences between the mutant lines and the control line. Boxed areas in $A$ and $C$ define areas shown at higher magnification in $B$ and $D$. epl, External plexiform layer; on, olfactory nerve layer. Scale bars: $A, C, 750 \mu \mathrm{m} ; B, D, 150 \mu \mathrm{m}$.

the level of stimulation of interneurons in the mitral compared with the periglomerular cell layer is normally lower and is reduced even further after naris closure. The resulting level of trans-synaptic activation is thus below the threshold for transcriptional induction of $\beta$-gal, and presumably $\mathrm{TH}$, in the interneurons of the mitral cell layer. The findings suggest that low-level stimulation may continue in the periglomerular region. Supporting this hypothesis is the significant loss of $\beta$-gal-stained processes within the glomeruli and the maintenance of perikaryal staining. A concurrent mechanism may be increased migration of neurons from the mitral to the periglomerular cell layer as a consequence of apoptotic cell loss in the glomerular layer (Najbauer and Leon, 1995; Fiske and Brunjes, 2001). Because previous studies suggested unchanged interneuron migration in the RMS after either naris closure or even bulbectomy (Frazier-Cierpial and Brunjes, 
1989; Kirschenbaum et al., 1999), replacement rates may be insufficient to maintain normal numbers of $\beta$-gal-expressing cells in the mitral cell layer. The finding that the highest density of apoptotic cells occurs in the superficial granule cells of the mitral cell layer after neonatal naris closure (Najbauer and Leon, 1995) suggests that cell death also may contribute to the reduction in the number of $\beta$-gal-expressing cells in this region of the OB.

Studies of transgenic mouse lines carrying a construct with a mutant AP-1 site in the context of an $8.9 \mathrm{~kb}$ TH promoter-lacZ reporter gene confirmed and extended previous studies that suggested the importance of this cis-acting element for $\mathrm{TH}$ gene expression in the OB (Yoon and Chikaraishi, 1994; NagamotoCombs et al., 1997; Liu et al., 1998). The three lines of transgenic mice with the mutant AP-1 construct had dramatically lower $\beta$-gal activity in the $\mathrm{OB}$ compared with mice expressing a transgene with the normal TH AP-1 site. Immunocytochemical analysis showed that the reduced $\beta$-gal activity was the result of decreased staining in both the mitral and periglomerular cell layers. In contrast, $\beta$-gal activity in the SN was either not different or higher in mice expressing the mutant construct. Previous transgenic mouse studies that also suggested a role for the AP-1 site in TH gene expression used a shorter promoter $(5.6 \mathrm{~kb})$ that supported transgene expression during embryogenesis but not in adult animals (Trocme et al., 1997, 1998). Other findings indicated that OB-specific TH expression required sequences upstream of the largest promoter (6 kb) used (Liu et al., 1997), substantiating the use of the $8.9 \mathrm{~kb}$ construct in the present study. In agreement with previous reports showing activity-dependent expression of c-Fos and FosB in DA cells of the OB and not the SN (Guthrie et al., 1993; Weiser et al., 1993; Guthrie and Gall, 1995a; Jin et al., 1996; Liu et al., 1999), these findings provide additional evidence that TH gene regulation through the AP-1 site is tissue specific and shows activity dependence in the OB (Trocme et al., 1997, 1998).

In summary, our findings demonstrate that during migration of DA progenitors from the SVZa through the granule cell layer to the periglomerular layer, two populations of granule cells can be distinguished, suggesting that the DA phenotypic differentiation occurs before the cells reach their final destination. Transcription of the TH gene occurs in the absence of significant translational activity, indicating that differentiation of the dopamine phenotype can occur in a stepwise manner. Lastly, the data support an important role for the TH AP-1 site in regulation of $\mathrm{TH}$ gene expression in the $\mathrm{OB}$.

\section{REFERENCES}

Alvarez-Buylla A, Temple S (1998) Stem cells in the developing and adult nervous system. J Neurobiol 36:105-110.

Anderson S, Mione M, Yun K, Rubenstein JL (1999) Differential origins of neocortical projection and local circuit neurons: role of Dlx genes in neocortical interneuronogenesis. Cereb Cortex 9:646-654.

Anderson SA, Eisenstat DD, Shi L, Rubenstein JL (1997a) Interneuron migration from basal forebrain to neocortex: dependence on Dlx genes. Science 278:474-476.

Anderson SA, Qiu M, Bulfone A, Eisenstat DD, Meneses J, Pedersen R, Rubenstein JL (1997b) Mutations of the homeobox genes Dlx-1 and Dlx-2 disrupt the striatal subventricular zone and differentiation of late born striatal neurons. Neuron 19:27-37.

Baker H (1990) Unilateral, neonatal olfactory deprivation alters tyrosine hydroxylase expression but not aromatic amino acid decarboxylase or GABA immunoreactivity. Neuroscience 36:761-771.

Baker H, Farbman AI (1993) Olfactory afferent regulation of the dopamine phenotype in the fetal rat olfactory system. Neuroscience 52:115-134.

Baker H, Kawano T, Margolis FL, Joh TH (1983) Transneuronal regulation of tyrosine hydroxylase expression in olfactory bulb of mouse and rat. J Neurosci 3:69-78.

Baker H, Kawano T, Albert VR, Joh TH, Reis DJ, Margolis FL (1984)
Olfactory bulb dopamine neurons survive deafferentiation induced loss of tyrosine hydroxylase. Neuroscience 11:605-615.

Baker H, Towle AC, Margolis FL (1988) Differential afferent regulation of the dopamine and GABAergic systems of the mouse main olfactory bulb. Brain Res 450:69-80.

Baker H, Morel K, Stone DM, Maruniak JA (1993) Adult naris closure profoundly reduces tyrosine hydroxylase expression in mouse olfactory bulb. Brain Res 614:109-116.

Baker H, Cummings DM, Munger SD, Margolis JW, Franzen L, Reed RR, Margolis FL (1999) Targeted deletion of a cyclic nucleotide-gated channel subunit (OCNC1): biochemical and morphological consequences in adult mice. J Neurosci 19:9313-9321.

Betarbet R, Zigova T, Bakay RA, Luskin MB (1996) Dopaminergic and GABAergic interneurons of the olfactory bulb are derived from the neonatal subventricular zone. Int J Dev Neurosci 14:921-930.

Brock SC, Bonsall J, Luskin MB (1998) The neuronal progenitor cells of the forebrain subventricular zone: intrinsic properties in vitro and following transplantation. Methods 16:268-281.

Brunjes PC, Smith-Crafts LK, McCarty R (1985) Unilateral odor deprivation: effects on the development of olfactory bulb catecholamines and behavior. Brain Res Dev Brain Res 22:1-6.

Cho JY, Min N, Franzen L, Baker H (1996) Rapid down-regulation of tyrosine hydroxylase expression in the olfactory bulb of naris-occluded adult rats. J Comp Neurol 369:264-276.

Doetsch F, Alvarez-Buylla A (1996) Network of tangential pathways for neuronal migration in adult mammalian brain. Proc Natl Acad Sci USA 93:14895-14900.

Doetsch F, Caille I, Lim DA, Garcia-Verdugo JM, Alvarez-Buylla A (1999a) Subventricular zone astrocytes are neural stem cells in the adult mammalian brain. Cell 97:703-716.

Doetsch F, Garcia-Verdugo JM, Alvarez-Buylla A (1999b) Regeneration of a germinal layer in the adult mammalian brain. Proc Natl Acad Sci USA 96:11619-11624

Enslen H, Sun P, Brickey D, Soderling SH, Klamo E, Soderling TR (1994) Characterization of $\mathrm{Ca}^{2+} /$ calmodulin-dependent protein $\mathrm{ki}$ nase IV. Role in transcriptional regulation. J Biol Chem 269:15520-15527.

Fiske BK, Brunjes PC (2001) Cell death in the developing and sensorydeprived rat olfactory bulb. J Comp Neurol 431:311-319.

Frazier-Cierpial L, Brunjes PC (1989) Early postnatal cellular proliferation and survival in the olfactory bulb and rostral migratory stream of normal and unilaterally odor-deprived rats. J Comp Neurol 289:481-492.

Gesteland RC, Yancey RA, Farbman AI (1982) Development of olfactory receptor neuron selectivity in the rat fetus. Neuroscience 7:3127-3136.

Graziadei PPC, Monti Graziadei GA (1980) Neurogenesis and neuron regeneration in the olfactory system of mammals. III. Deafferentation and reinnervation of the olfactory bulb following section of the filia olfactoria in rat. J Neurocytol 9:145-162.

Guthrie KM, Gall CM (1995a) Functional mapping of odor-activated neurons in the olfactory bulb. Chem Senses 20:272-282.

Guthrie KM, Gall CM (1995b) Odors increase Fos in olfactory bulb neurons including dopaminergic cells. NeuroReport 6:2145-2149.

Guthrie KM, Anderson AJ, Leon M, Gall C (1993) Odor-induced increases in c-fos mRNA expression reveal an anatomical "unit" for odor processing in olfactory bulb. Proc Natl Acad Sci USA 90:3329-3333.

Hinds JW (1968a) Autoradiographic study of histogenesis in the mouse olfactory bulb. I. Time of origin of neurons and neuroglia. J Comp Neurol 134:287-304.

Hinds JW (1968b) Autoradiographic study of histogenesis in the mouse olfactory bulb. II. Cell proliferation and migration. J Comp Neurol 134:305-322.

Inouye S, Inouye M (1987) Oligonucleotide-directed site-specific mutagenesis using double-stranded plasmid DNA. In: DNA and RNA synthesis (Narang S, ed), pp 181-206. New York: Academic.

Jin BK, Franzen L, Baker H (1996) Regulation of c-Fos mRNA and fos protein expression in olfactory bulbs from unilaterally odor-deprived adult mice. Int J Dev Neurosci 14:971-982.

Kirschenbaum B, Doetsch F, Lois C, Alvarez-Buylla A (1999) Adult subventricular zone neuronal precursors continue to proliferate and migrate in the absence of the olfactory bulb. J Neurosci 19:2171-2180.

Kroll SL, Paulding WR, Schnell PO, Barton MC, Conaway JW, Conaway RC, Czyzyk-Krzeska MF (1999) von Hippel-Lindau protein induces hypoxia-regulated arrest of tyrosine hydroxylase transcript elongation in pheochromocytoma cells. J Biol Chem 274:30109-30114.

Law SW, Conneely OM, DeMayo FJ, O'Malley BW (1992) Identification of a new brain-specific transcription factor, NURR1. Mol Endocrinol 6:2129-2135.

Liu J, Merlie JP, Todd RD, O'Malley KL (1997) Identification of cell type-specific promoter elements associated with the rat tyrosine hydroxylase gene using transgenic founder analysis. Brain Res Mol Brain Res 50:33-42.

Liu N (2000) Regional distribution of protein kinases in normal and odor-deprived mouse olfactory bulbs. Chem Senses 25:401-406. 
Liu N, Baker H (1999) Activity-dependent Nurr1 and NGFI-B gene expression in adult mouse olfactory bulb. NeuroReport 10:747-751.

Liu N, Tinti C, Joh TH, Baker H (1998) AP1 and CRE elements mediate regulation of both basal and inducible tyrosine hydroxylase promoter activities. Soc Neurosci Abstr 24:1598.

Liu N, Cigola E, Tinti C, Jin BK, Conti B, Volpe BT, Baker H (1999) Unique regulation of immediate early gene and tyrosine hydroxylase expression in the odor-deprived mouse olfactory bulb. J Biol Chem 274:3042-3047.

Lois C, Alvarez-Buylla A (1993) Proliferating subventricular zone cells in the adult mammalian forebrain can differentiate into neurons and glia. Proc Natl Acad Sci USA 90:2074-2077.

Lois C, Garcia-Verdugo JM, Alvarez-Buylla A (1996) Chain migration of neuronal precursors. Science 271:978-981.

Luskin MB (1993) Restricted proliferation and migration of postnatally generated neurons derived from the forebrain subventricular zone. Neuron 11:173-189.

Makeyev AV, Chkheidze AN, Liebhaber SA (1999) A set of highly conserved RNA-binding proteins, $\alpha \mathrm{CP}-1$ and $\alpha \mathrm{CP}-2$, implicated in mRNA stabilization, are coexpressed from an intronless gene and its intron-containing paralog. J Biol Chem 274:24849-24857.

Matthews RP, Guthrie CR, Wailes LM, Zhao X, Means AR, McKnight GS (1994) Calcium/calmodulin-dependent protein kinase types II and IV differentially regulate CREB-dependent gene expression. Mol Cell Biol 14:6107-6116.

McLean JH, Shipley MT (1988) Postmitotic, postmigrational expression of tyrosine hydroxylase in olfactory bulb dopaminergic neurons. J Neurosci 8:3658-3669.

McLean JH, Shipley MT (1991) Postnatal development of the noradrenergic projection from locus coeruleus to the olfactory bulb in the rat. J Comp Neurol 304:467-477.

Menezes JR, Smith CM, Nelson KC, Luskin MB (1995) The division of neuronal progenitor cells during migration in the neonatal mammalian forebrain. Mol Cell Neurosci 6:496-508.

Min N, Joh TH, Kim KS, Peng C, Son JH (1994) 5' Upstream DNA sequence of the rat tyrosine hydroxylase gene directs high-level and tissue-specific expression to catecholaminergic neurons in the central nervous system of transgenic mice. Brain Res Mol Brain Res 27:281-289.

Min N, Joh TH, Corp ES, Baker H, Cubells JF, Son JH (1996) A transgenic mouse model to study transsynaptic regulation of tyrosine hydroxylase gene expression. J Neurochem 67:11-18.

Nadi NS, Head R, Grillo M, Hempstead J, Granno-Reisfeld N, Margolis FL (1981) Chemical deafferentation of the olfactory bulb: plasticity of the levels of tyrosine hydroxylase, dopamine, and norepinephrine. Brain Res 213:365-377.

Nagamoto-Combs K, Piech KM, Best JA, Sun B, Tank W (1997) Tyrosine hydroxylase gene promoter activity is regulated by both cyclic AMP-responsive element and AP1 sites following calcium influx. J Biol Chem 272:6051-6058.

Najbauer J, Leon M (1995) Olfactory experience modulated apoptosis in the developing olfactory bulb. Brain Res 674:245-251.

Parnavelas JG (2000) The origin and migration of cortical neurones: new vistas. Trends Neurosci 23:126-131.

Parnavelas JG, Anderson SA, Lavdas AA, Grigoriou M, Pachnis V, Rubenstein JL (2000) The contribution of the ganglionic eminence to the neuronal cell types of the cerebral cortex. Novartis Found Symp 228:129-139

Puche AC, Shipley MT (1999) Odor-induced, activity-dependent transneuronal gene induction in vitro: mediation by NMDA receptors. J Neurosci 19:1359-1370.

Redmond L, Hockfield S, Morabito MA (1996) The divergent ho- meobox gene PBX1 is expressed in the postnatal subventricular zone and interneurons of the olfactory bulb. J Neurosci 16:2972-2982

Saucedo-Cardenas O, Quintana-Hau JD, Le WD, Smidt MP, Cox JJ, De Mayo F, Burbach JP, Conneely OM (1998) Nurr1 is essential for the induction of the dopaminergic phenotype and the survival of ventral mesencephalic late dopaminergic precursor neurons. Proc Natl Acad Sci USA 95:4013-4018.

Schimmel JJ, Crews L, Roffler-Tarlov S, Chikaraishi DM (1999) $4.5 \mathrm{~kb}$ of the rat tyrosine hydroxylase $5^{\prime}$ flanking sequence directs tissue-specific expression during development and contains consensus sites for multiple transcription factors. Brain Res Mol Brain Res 74:1-14.

Smidt MP, Asbreuk CH, Cox JJ, Chen H, Johnson RL, Burbach JP (2000) A second independent pathway for development of mesencephalic dopaminergic neurons requires Lmx1b. Nat Neurosci 3:337-341.

Stone DM, Wessel T, Joh TH, Baker H (1990) Decrease in tyrosine hydroxylase, but not aromatic L-amino acid decarboxylase, messenger RNA in rat olfactory bulb following neonatal, unilateral odor deprivation. Brain Res Mol Brain Res 8:291-300.

Stone DM, Grillo M, Margolis FL, Joh TH, Baker H (1991) Differential effect of functional olfactory bulb deafferentation on tyrosine hydroxylase and glutamic acid decarboxylase messenger RNA levels in rodent juxtaglomerular neurons. J Comp Neurol 311:223-233.

Stone DM, Hynes M, Armanini M, Swanson TA, Gu Q, Johnson RL, Scott MP, Pennica D, Goddard A, Phillips H, Noll M, Hooper JE, de Sauvage F, Rosenthal A (1996) The tumour-suppressor gene patched encodes a candidate receptor for Sonic hedgehog. Nature 384:129-134.

Suhonen JO, Peterson DA, Ray J, Gage FH (1996) Differentiation of adult hippocampus-derived progenitors into olfactory neurons in vivo. Nature 383:624-627.

Tinti C, Yang C, Seo H, Conti B, Kim C, Joh TH, Kim K-S (1997) Structure/function relationship of the cAMP response element in tyrosine hydroxylase gene transcription. J Biol Chem 272:19158-19164.

Trocme C, Mallet J, Biguet NF (1997) AP-1 mediates trans-synaptic induction of tyrosine hydroxylase gene expression in adrenal medulla but not in superior cervical ganglia. J Neurosci Res 48:489-498.

Trocme C, Sarkis C, Hermel JM, Duchateau R, Harrison S, Simonneau M, Al-Shawi R, Mallet J (1998) CRE and TRE sequences of the rat tyrosine hydroxylase promoter are required for $\mathrm{TH}$ basal expression in adult mice but not in the embryo. Eur J Neurosci 10:508-521.

Weiser M, Baker H, Wessel TC, Joh TH (1993) Axotomy-induced differential gene induction in neurons of the locus ceruleus and substantia nigra. Brain Res Mol Brain Res 17:319-327.

Wichterle H, Garcia-Verdugo JM, Herrera DG, Alvarez-Buylla A (1999) Young neurons from medial ganglionic eminence disperse in adult and embryonic brain. Nat Neurosci 2:461-466.

Yang XW, Zhong R, Heintz N (1996) Granule cell specification in the developing mouse brain as defined by expression of the zinc finger transcription factor RU49. Development 122:555-566.

Ye W, Shimamura K, Rubenstein JL, Hynes MA, Rosenthal A (1998) FGF and Shh signals control dopaminergic and serotonergic cell fate in the anterior neural plate. Cell 93:755-766.

Yoon SO, Chikaraishi DM (1994) Isolation of two E-box binding factors that interact with the rat tyrosine hydroxylase enhancer. J Biol Chem 269:18453-18462

Zetterstrom RH, Williams R, Perlmann T, Olson L (1996) Cellular expression of the immediate early transcription factors Nurr1 and NGFI-B suggests a gene regulatory role in several brain regions including the nigrostriatal dopamine system. Brain Res Mol Brain Res 41:111-120.

Zetterstrom RH, Solomin L, Jansson L, Hoffer BJ, Olson L, Perlmann T (1997) Dopamine neuron agenesis in Nurr1-deficient mice. Science $276: 248-250$ 